\title{
IDENTIFICATION AND CONSERVATION OF GEOHERITAGE (GEOLOGY) BASED ON GEODIVERSITY ANALYSIS (ASPIRING GEOPARK): STUDY OF KALTARA AND SANGKULIRANG-MANGKALIHAT
}

\author{
Mohamad Sapari Dwi Hadian*, Mochamad Nursiyam Barkah, Puja Rana Ramadhan, \\ Bombom Rahmat \\ Universitas Padjadjaran, Indonesia
}

\begin{abstract}
Aspiring geopark of Krayan Highland (Kaltara) and Sangkulirang-Mangkalihat mountain range is a geoheritage located in Northeast Kalimantan. The diversity of its nongeological aspects is located at the forests with High Conservation Value. Based on its intrinsic value, geosite is grouped within geological hotspots into diverse value areas (geoarea), by compiling them into data of geodiversity, biodiversity, and culturediversity. This inventory establishes 16 geosite types that are possible in 10 geological frameworks: anthropogeny, sedimentology, paleontology, mineralogy, stratigraphy, igneous rocks, metamorphic rocks, structural geology, neotectonics, geomorphology, hydrology and hydrogeology, geochemistry, geothermal, economics, paleogeography, and geohistory. Some sites are worth extraordinary and amazing Sites of Special Scientific Interest (SSSIs) and Regionally Important Geological and Geomorphological Sites (RIGS). Several geoheritage sites hold valuable evidence of Cenozoic magmatism and obduction, atoll and modern carbonate landscape, as well as distinctive hydrological features. Scientific meaning is close to the true value of the potential aspect. Its' geological and landscape structures affect cultural tradition and biodiversity, forcing them to adapt. The geoheritage sites of Kaltara and Sangkulirang-Mangkalihat are popular in local, regional and national as well as global tourism spot.
\end{abstract}

Keywords: geodiversity, geoheritage, aspiring geopark, geoconservation

\section{Introduction}

Geological diversity or geodiversity includes all material variability of the earth's surface, physical processes, and landscapes (Hjort and Gray, 2015). The geodiversity can be calculated (Ruban, 2010), where descriptive and quantitative analysis the geodiversity is beneficial for geoconservation. As an important aspect in geological heritage (geoheritage) features, geology plays an essential function in all life because of its importance (Prosser et al., 2006), including features for science, education and tourism. Geological heritage, which is basically geodiversity, has been recognized as a new type of geological resource (Wimbledon, 1996; Prosser et al., 2006; Ruban, 2010, 2017; Sallam et al, 2018; Águeda Villar, J.A., et al., 2009). Águeda Villar et al. (2009) explained that geological heritage was defined as a set of geological resources with scientific, cultural, and educational values (geological formations and structures, landscapes, minerals, rocks, fossils, soil, etc.) to understand, study and interpret the earth's geological history of the earth, the processes that modeled it, the past and present climate and landscapes, and the origin and evolution of life on this planet. The sustainable use of geological resources for scientific, educational, or recreational/tourism purposes makes it necessary to have the understanding about the geodiversity damage, either by natural or anthropogenic causes (Ruban, 2010). In this case, the protection and preservation of geological and/or geomorphological features is referred to as geoconservation. 
There are not many research on geodiversity in North Kalimantan (Kaltara) and East Kalimantan (SangkulirangMangkalihat and Derawan Islands. Previous geological, biological, and cultural research can be found (Asmoro, 2016; Baharuddin, 2011; Baillie et al., 2004; Hartono, 1985; Hutchison, 1998; Metcalfe, 1996, 2011; Moss, and Wilson1998; KepMen, 2000; Wilson et al., 1998; 2002; Salas et al., 2005; Soeria-Atmaja et al., 1999; Sulistyawan, 2013; Susanto, 2016; Chazine, 2005; Chazine et al., 2008; Dermawan, 2014; Eghenter, 2000; Gani, 2012; Hantoro, 2009; Groupe, 2010; Thompson et al., 2010; Tomascikand, 1994; Langub, 2012; Paddenburg et al., 2012; Sugiyanto, 2012). These studies emphasized on descriptions of the conditions, situations, and characteristics and/or traditions of the area, and have not incorporated the geopark concept. There is little knowledge related to geoheritage and geopark. Although the quality of the UNESCO natural, cultural and geoheritage candidate site is unquestionable, this knowledge is only limited to raising awareness on the values of culture and biodiversity, not geology. Unique and amazing geological and geomorphological features are very diverse in Kalimantan.

The purpose of this paper is to uncover geological heritage diversity Aspiring Geopark in the North, Northeast, and Easternmost (the "nose" part - Tanjung Mangkalihat) parts of the island of Kalimantan on the basis of the synthesis of the relevance of secondary documents and objective-subjective interpretations, for the development of the Aspiring Geopark itself. Identification (to reveal Outstanding Universal Value - OUA, see UNESCO WHC, 2017) on features, types, and parts of geological diversity, which are important, on a large or small scale, that have the potential to be raised will presented in this paper. The geological heritage sites (geosite) will be selected, and other implications for protecting the site and promoting geoconservation will be presented as well.

\section{Geological Order}

North Kalimantan (Kaltara) has a plain to hilly topography along with central mountains of Kalimantan (the Kinabalu-massif Iban-Schwaner mountain range, see Van Bemmelen, 1949), which extends from the Southwest to Northeast orientation of the island. It is classified as coastal lowlands, marshland, and also lowlands of fluvial origin, lowlands of inland karst, which are the products of a strong denudation process to develop hilly outcrops until forming a series of mountains, great meandering rivers, horseshoe lakes, deltas, unique collection of karst hills (Sangkulirang-Mangkalihat), and atoll coral complex (Berau sea coast).

The tectonic development of Kalimantan is influenced by the interaction of the Sunda plate (West) with the Pacific plate to the east, the Australian Indian plate to the south, and the South China Sea plate to the north. In Moss and Wilson (1998), Kalimantan is interpreted as the product of Mesozoic accretion of oceanic crust material (ophiolite), marginal basin fill, archipelago arc material, microcontinental fragments, and core of the Paleozoic continent from the Schwaner Mountains in the southwest of the island. Baillie et al (2004) outlined the tectonics of Kalimantan into: (i) Paleogene tectonic events, the development of parts of the Sundaland (Hutchinson, 1996), extensionality in the Makassar Strait, and strong regional compression in Northwest part of Kalimantan, (ii) Neogene Compression, uplifting of Kalimantan and a significant increase in sediment production resulting in a series of delta systems built up along Kalimantan, (iii) MOR in the South China Sea, occurring in the Middle Oligocene-Miocene, (iv) Neogeneous collisions with Australian crust material.

Kalimantan volcanic activity occurs during the Tertiary events. The magmatic strip running northeast-southwest associated with two different subduction periods; during the Eocene-Oligocene and the late Oligocene-Miocene (Soeria-Atmaja et al., 1999).

The bedrock is composed of a collection of igneous rocks, metamorphic rocks, and mid-Paleozoic sedimentary rocks (Baillie et al., 2004). North Kalimantan consists of the high central mountains of Kalimantan and the North Kalimantan basin. The constituent rocks which are deposited in the old sedimentary basin arrangement are controlled by the support period and plate expansion. The Kalimantan accretion zone is Mesozoic deposits (Early Tertiary) of deep sea sediments, mafic rocks, igneous rocks, and melange complexes. In coastal areas in modern basins, Cenozoic sediments including volcanic rocks are deposited as evidence of the Cenozoic 
magmatism phase (Moss and Wilson, 1998). The bedrock in the North Kalimantan basin consists of old sediments, including lake formations, Sembakung formations, and Malio claystone. The sediments are lithified and deformed. The lake formation is strongly deformed and undergoes metamorphosis, containing serpentinitized breccias, radiolaria chert, sphilit, shale, slate, and quartz. The Sembakung Formation is deposited on top of the Lake Formation inconsistently. This formation consists of volcanic and clastic sediments of the Early Eocene-Middle Eocene age. The Sembakung Formation is overlain by fossilized claystone, carbonate, and Middle Eocene Mica (Malio claystone; Heriyanto, 1991). In the Tanjung Mangkalihat section, carbonate sediments of the Kedango formation, the Tabalar formation, the Domaring formation, the Tendehantu formation, the Seilor formation, the pre-Tertiary sediments, and the ophiolite complex are deposited. Seilor formation, Tabalar formation, Tendehantu formation, and Domaring formation are deposited in the Late Eocene to Mio-Pliocene, an extensive carbonate exposure and isolated uplift as well as reworking along the continental margins. The deposited lithology is framestones, rudstones, packstones, grainstones, wackestones, and dolomites. Kedango formation is deposited in the Late Eocene in the form of carbonate exposure as well as slope and deep sea facies sediments. The lithology is deposited in the form of packstones, wackestones, rudstones, conglomerates, and marl (Wilson et al., 1998; 2002).

\section{Methodology}

Geodiversity derived from three aspects described by Hjort and Gray (2015) namely landscapes, earth surface materials, and physical processes. Geosite typology includes rock sections, areas, viewpoints, and geosite complexes (Fernández-Martínez and Fuertes-Gutiérrez, 2010). Geodiversity classification and calculations are based on the development with an assessment of interest features of the geosite quantity, geosite types, types of geosite sections/subtypes, geodiversity loci/hotspots, and the relative value of each geosite (Rubin, 2010).

As a general rule, following Moura et al. (2017), a list of potential geosites is identified from, i) Definition of geological order and relevant relationships with geosites that represent geological occurrence (geoevidence) and content of non-geological scientific significance; ii) Geological outcrops; iii) Unique, rare, elevated, and prominent geological and geomorphological featuresiv) karst landscape area of the Ministry of Energy and Mineral Resources (2000, 2012), UNESCO Global Geopark (2014), and IUCN World Comission on Protected Areas (1997). The geosite is also evaluated based on the existing Indonesian legal framework. However, the geosite is still selected within the scope of the relevant literature and only a very small part has been verified in real/field.

The quality assessment is based on the concept of Ruban (2010) and Neches (2016) by determining the interpretation score (IS - Interpretation Score) and heritage value (HV - Heritage Value) of each geosite and considering the scientific aspects of geology. Further identification, the geological heritage is adapted based on a representative assessment of the geological elements present within the sites, a modification from Ibrahim Komoo and Law No. 26/2007 (Andriany, 2015). Geoconservation analysis uses a site type approach based on the Earth Science Conservation Classification (ESCC; Prosser et al., 2006), comparing it with biodiversity and culturdiversity.

Overlapping analysis with non-geological components is carried out to analyze development plans of geological area, zoning systems, and geoconservation applications. The data used are existing maps of Kalimantan conservation areas, IUPPHK, and other development criteria. The GIS MapInfo Professional v10 program is used to perform this analysis with the output of maps of overlapping results and zoning areas of geological diversity. 


\section{Results and Discussions}

\section{Geodiversity}

In this study, 299 various geological features (geodiversity) have been inventoried and mapped, obtained through field activities. Existing data can be updated until other geological features are found and/or the importance status (score and value) of old geosites changes. This is realtime data exposed as geological features on the earth's surface, apart from the potential data of the area seen from the diversity of rock units, land units, and landscape units that still need further investigations. From all the scattered geological features, 48 were selected as geosites including simple and complex features and 8 geological LOCI/hotspots.

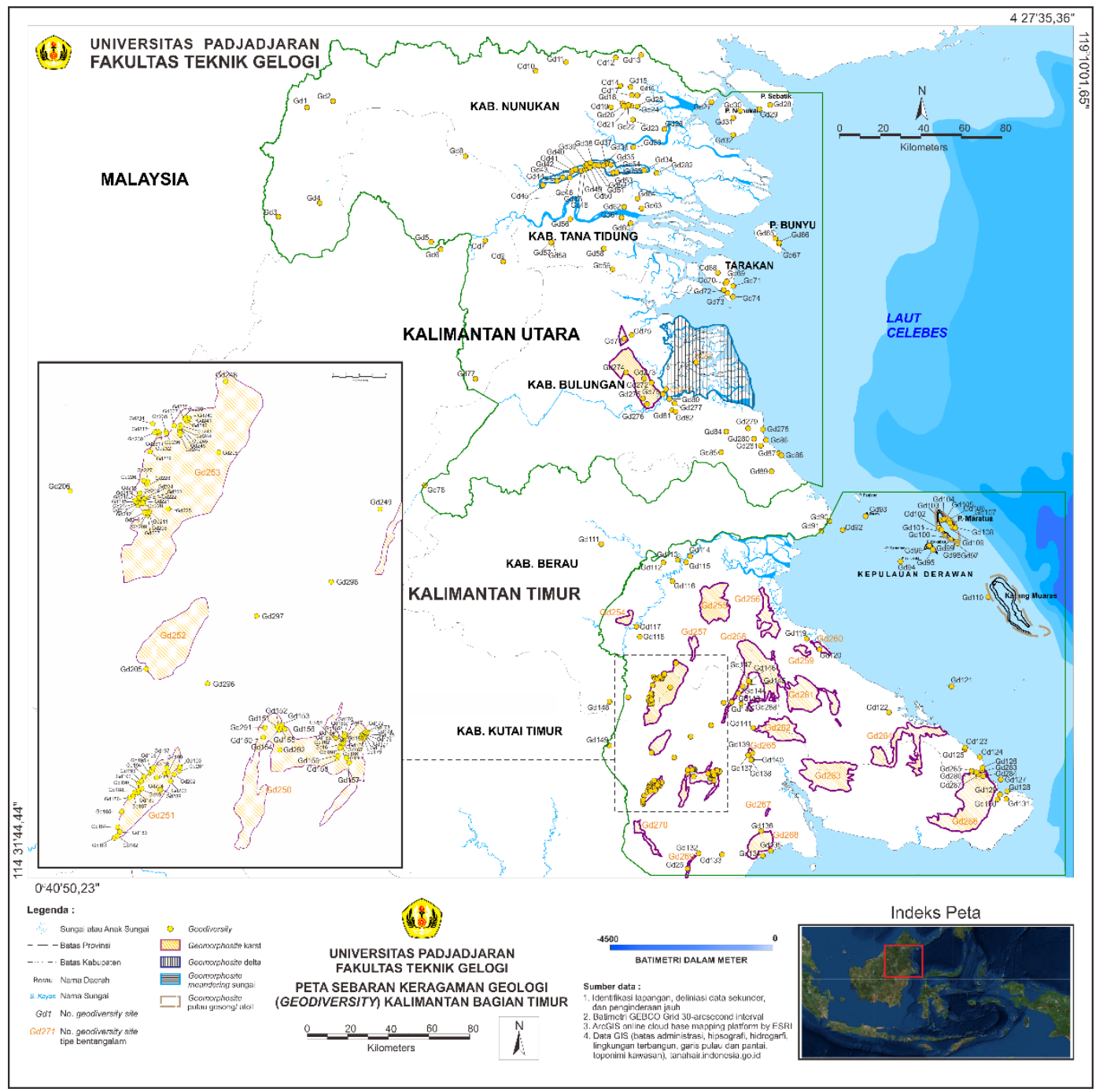

Figure 1. Distribution of geological diversity in Eastern Kalimantan (with bathimetric data GEBCO Grid 30 arc-second interval [2014])

\section{Calculations of Geodiversity (Geodiveristy1, Geoabundance1, Georichness1)}

\section{Geoarea 1 - North Kalimantan (Kaltara)}

Geoarea 1 has 53 geosites are purely seen as simple type. If the complex geosites are considered, then the number becomes 26 geosites. However, this is still limited to the number of objects or a collection of objects - a value of geological abundance (geoabundance1), not yet considered based on other geosite types, (other 
geological abundances in geosite types [Geosite per Geosite types], see appendix 5). The geological heritage site consists of 23 different geological objects, most of which are forms or landscapes or original geological features from hydrogeomorphological processes (e.g. oxbow lakes, stream sections, deltas, and beaches), karst original formations (caves, karst mountain segments, uniquely shaped rocks), and ancient volcanoes. Geosites are evenly distributed throughout the geoarea over a distance of up to tens of kilometers with no specific density of geosite. Except in one meandering system on the Sembakung River where the density of an oxbow lake is located. The Tarakan delta system where the Kayan river network is divided cuts many deltaic deposits into small scorched islands, as well as the ancient volcanic complex on the island of Nunukan.

Based on the genesis/origin and characteristics of geological heritage sites (Ruban, 2005; 2009; 2010), Geosite is classified into 15 (geodiversity1) types of geosites from 21 possible types: stratigraphy, sedimentology, igneous rock, metamorphic rock, paleontology, mineralogy, economy, geochemistry, structure, paleogeography, geothermal, geomorphology, hydrology \& hydrogeology, engineering, and geological history. The total number of geosite types has been considered regardless of how common and unique the geological features are. Not only that, there are also other geoscientific values and assets: speleology, local history, culture, anthropology, ecology, archeology, tourism, biology, geography, conservation, and teaching, education, and research (TER), based on

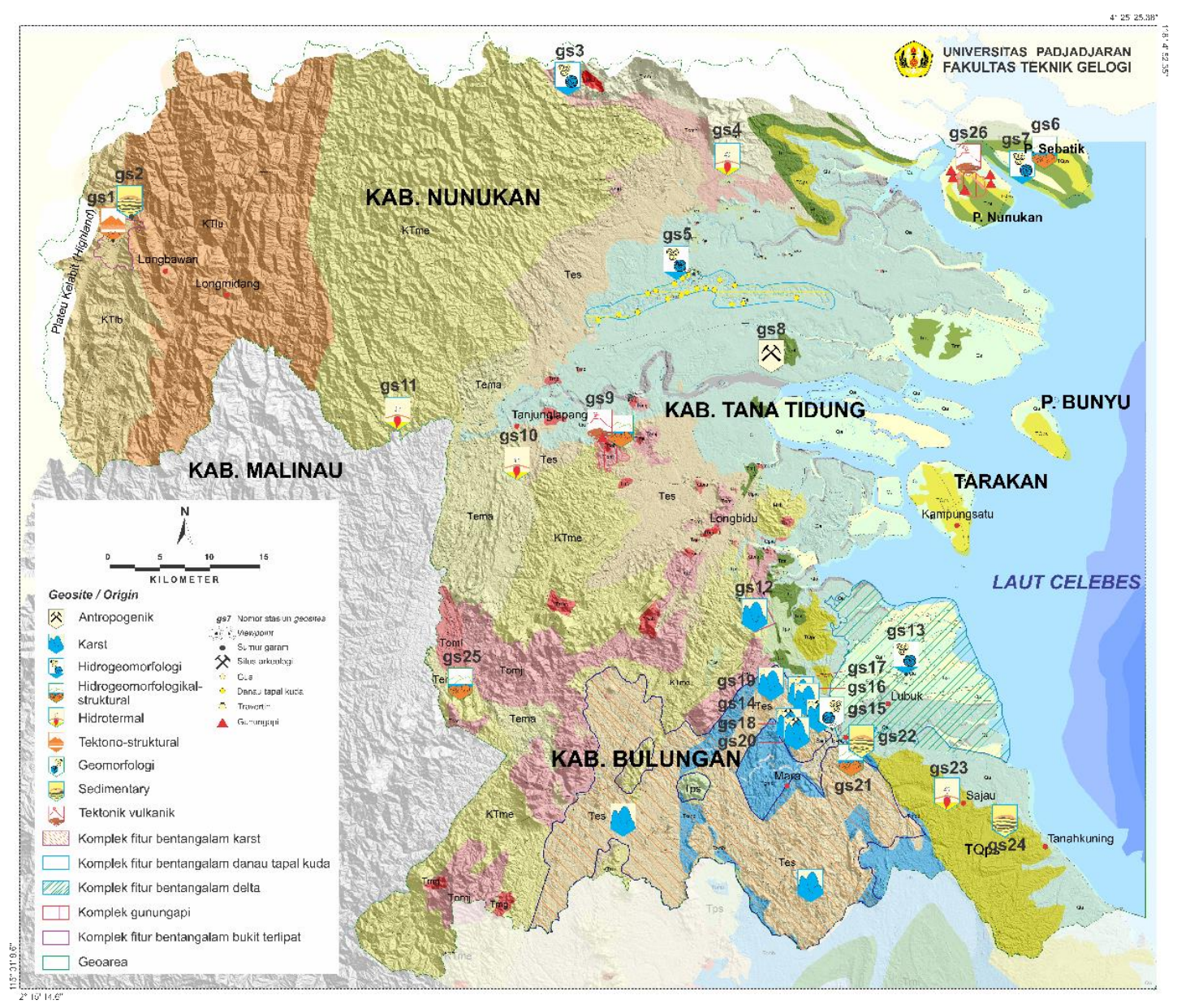

Figure 2. Selected geological heritage sites, simple and complex geosites, North Kalimantan area (also known as geoarea 1/territory 1 in the Eastern Region of the island of Kalimantan)

UNESCO Guidelines (2014). The value of geological richness (georichness1) in this geoarea is 173. The most common but not necessarily the lowest types of geosite in terms of value are sedimentology, hydrology and hydrogeology, and geomorphology, which cover $43.31 \%$ of the georichness (geodiversity of the geosite type) in 
geoarea 1 . The least values appear or the least common values and are not necessarily the most valuable types of geosite are engineering and metamorphic rocks which cover $0.63 \%$ of the existing georichness value.

\section{Geoarea 2 - East Kalimantan (Sangkulirang-Mangkalihat)}

Geoarea 2 has 178 geosites (homogeneous/simple geosites) or 22 geosites (heterogeneous/complex geosites). This is also the value of geological abundance (geoabundance1 or geological abundance per geosite type [Geosite per Geosite types], see appendix 6). This geological heritage site includes 21 different geological objects. Most of these objects are forms or landscapes or geological features of karst origin (e.g. special karst landscapes; dolina, uvala, polje, caves, rimstone pools, karst mountain segments, karst towers, karst cockpits, karst heights, karst cones, as well as stream sections).

Geosites are classified into 14 (geodiversity1) types of geosites from 21 possible types (Ruban, 2005; 2009; 2010): sedimentology, petrology; igneous rock, metamorph, mineralogy, economics, paleontology, geochemistry, structure, neotectonics, paleogeography, geothermal, geomorphology, hydrology and hydrogeology, and geological history. The entire geosite type is considered regardless of how unique and common the geosite feature. The values of geoscience and other assets include: speleology, local history, culture, anthropology, ecology, archeology, tourism, biology, geography, conservation, and teaching, education, and research (TER), based on UNESCO Guidelines (2014). The value of geological richness (georichness1) in territory 2 is 184 . The most common types of geosite but not necessarily the lowest in terms of value are sedimentology, geohistory, and geomorphology, which cover $39.7 \%$ of the georichness (geodiversity of the geosite type) in geoarea 1. The least-occurring or least common value and not necessarily the most valuable geosite type is petrology: igneous and metamorphic rocks and neotectonics which cover $0.37 \%$ of the existing georichness value.

Geosites with their geological features are scattered and separated within the geoarea up to tens of kilometer distances. Geosites in this geoarea are defined as a complex type and combination of several points of geosites whose geosite determination is carried out based on larger scale geodiversity types (landscapes). The delineation is based on origin or specific landscape similarity and geographic distribution as well as by geological loci/hotspot grouping. In addition, it also takes advantage of the conditions of the unique landscape. In this case, the Sangkulirang-Mangkalihat karst as the largest karst-originated as geodiversity in the geoarea which is known for its tectonic settings is the Mangkalihat high, spread in the form of isolated karst mounds. The karst mounds/groups consist of many unique features that make up the 16 karst groups and 17 geosite groups. Other geosites include 3 atoll island geosites, 1 structural sedimentary mountain geosite, and 1 gulf bancuh rock complex (ophiolite), so that the geosite is mostly classified as a complex area. 


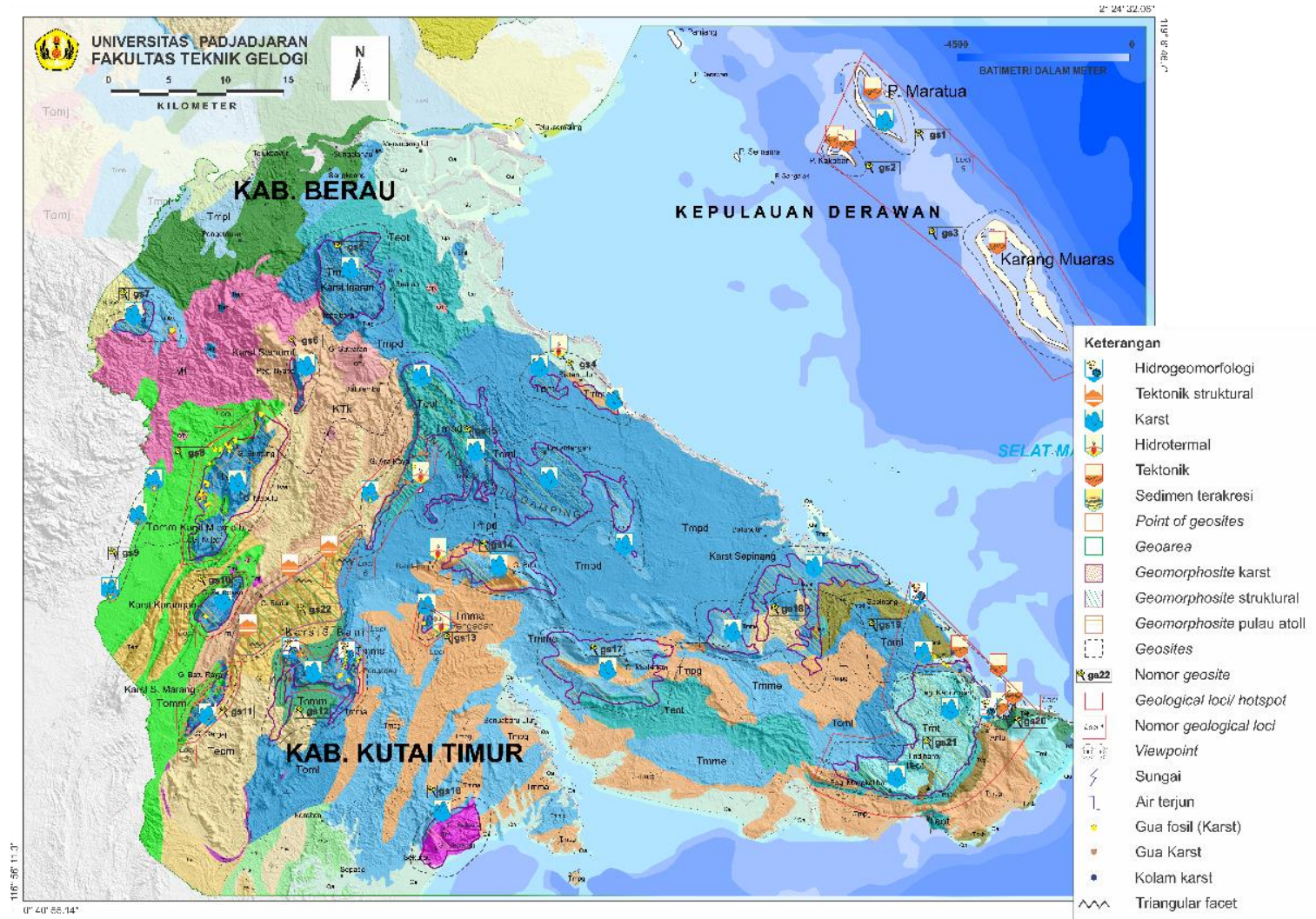

Figure 3. Selected geological heritage sites (geosites), simple and complex geosites, East Kalimantan area (also known as geoarea 2/territory 2 in the Easternmost Region of the island of Kalimantan)

The western, central, northeastern and southeastern parts of the geoarea are heterogeneous geosites as geodiversity locus/hotspots (Figure 3). There are 8 hotspots with 13 geosites and 14 geosite types. Some of the inventoried karst features have very high archaeological value spread over 5 loci (LOCI 1, LOCI 2, LOCI 3, LOCI 4, LOCI 6). As a result of the data distribution analysis, the determination of the hotspots is not final yet in the development of further research. It is because other areas are very likely to be explored with high level of abundance of geological diversity, in terms of tectonic, geological, and landscape orders.

Qualitative Assessment of Geodiversity (set an interpretation score [IS - Interpretation Score] and a heritage value [HV - Heritage Value])

Kaltara and Sangkulirang-Mangkalihat Geoareas are included in the regional scale (>10000 Km2 - Brocx and Semeniuk, 2007). Then, the score (heritage value) will only cover the local-regional scale range. However, if the geological features can be compared with other geological features in other geosites that have been recognized, then the geosite may get a national to global recognitions. This is based on the content of geological or cultural and biological values or the related relationship between them.

\section{Geoarea 1 - North Kalimantan (Kaltara)}

The Kaltara Geoarea consists of a large number of landscapes and outcrop manifestations that are formed as a result of tectonic processes, volcanoes, and sedimentological processes in sedimentary basins, fluvial, delta, karstification, and volcanic geothermal as well as those associated with sedimentary basins. This inventory defines 9 geological frameworks (Appendix 5) as the genesis/origin of the geological objects in the geoarea, following regional lithology, stratigraphy, and tectonics, represented in the justification of scientific values (Ramadan, 2018). Some of the most prominent and valuable sites mentioned in some geological literature include sites representing anhydrite accumulations and landscapes in old tectonic zones, ancient volcanoes, 
geothermal manifestations in the oldest rocks to manifestations associated with sedimentary basins, evidence of geological occurrences as the opener of the Tertiary magmatic arc process, the karst landscape and the alluvialfluvial land of the Tarakan basin.

\section{Geoarea 2 - East Kalimantan (Sangkulirang-Mangkalihat)}

The Sangkulirang-Mangkalihat Geoarea is occupied by karstified lithological outcrops and limestone landscapes, and the other small amounts of sediments and bancuh rock (melange). This inventory defines 5 geological frameworks (Appendix 6) based on genesis/origin, following regional lithology, stratigraphy, and tectonics, represented in scientific value justifications (Ramadan, P. R., 2018). Some of the most prominent and valuable sites mentioned in geological literatures are the carbonate kenozoic landscapes and outcrops and the ophiolite complex.

\section{Geodiversity2, Geodiversity3, Geoabundance2, Georichness2}

In the case of the Kaltara geodiversity (Geoarea 1), the maximum rating score is as follows (geosite with the maximum score is shown in brackets): stratigraphy - 0.001 (siltstone layer stratigraphy with limestone and sandstone inserts), sedimentary - 0.01 (Semolon travertine, Mount Krayan salt deposits, Sei Apok pyrite conglomerate), igneous rock - 0.01 (Tanjungbatu pillow lava, stocky column and stocky sheet of basalt andesite, microdiorite), metamorphic rocks - 0.01 (Sei Apok ancient volcano), paleontology - 0.001 (limestones of Batuputih and Tanah Kuning), mineralogy - 0.01 (salt dome of anhydrite deposit, Sei Apok lava sulfur flower), economy - 0.01 (Krayan mountain salt, Krayan adan rice), geochemistry - 0.001 (Jelai volcano), structure -0.01 (tectonics-structure of Krayan highlands), paleogeography - 0.01 (Tertiary karst hills, Nunukan ancient volcano), geothermal - 0.01 (non-volcanic geothermal), geomorphology - 0.01 (Tj. Selor alluvial-fluvial lowlands, the Krayan highlands and structural hills), hydrology and hydrogeology - 0.01 (Tarakan delta \& Sembakung meandering river), engineering - 0.001 (green lake), geohistory - 0.01 (Tertiary karst hills, Jelai volcano, Nunukan ancient volcano, anhydrites deposits and Krayan structural hills). The total score for this ranking is $0.114(0.54 \%$ of the geodiversity limit). All geosites are complex, and hence the value of geodiversity 3 is $100 \%$. The geological abundance value (geoabundance2) which is represented by the total number of geosites is 0.17 (calculated based on the geosite complex). This is only $0.65 \%$ of the total geosite amount. The actual geological richness (georichness2) in this geoarea is 1.55 , only $0.89 \%$ of the total value of 173 , and is further away from the maximum value of 390 .

Sangkulirang-Mangkalihat Geodiversity (Geoarea 2), the maximum ranking score is as follows: sedimentary 0.01 (pre-Tertiary sediments of Teluk Sumbang, Cenozoic carbonate), igneous rocks - 0.01 (various igneous rocks of ophiolite complex), metamorphic rocks -0.01 (various ophiolite complex metamorphic rocks), paleontology - 0.01 (Cenozoic limestone large foraminifera), mineralogy - 0.001 (calcite and quartz veins), economy - 0.1 (geotourism), geochemistry - 0.001 , structure - 0.01 (triangular facet ridge/ravine), neotectonics 0.01 (triangular facet fault line), paleogeography - 1 (Cenozoic carbonate), geothermal - 0.01 (non-volcanic geothermal), geomorphology - 1 (Sangkulirang-Mangkalihat karst landscape, atoll coral), hydrology \& hydrogeology - 0.1 (tebot lake, rimstone pond), geohistory - 1 (Cenozoic carbonate). All geosites are complex ( $100 \%$ - geodiversity 3 ), and therefore the value of geodiversity 2 is 3.272 (23.27\% of the geodiversity limit). The geological abundance value (geoabundance2) based on its complexity is 20.02 , from the total geosites that exist, as much as $91 \%$ of the total number of geosites. The actual geological richness (georichness2) in this geoarea is 69.655 , only $37.85 \%$ of the total value of 184 , and is further away from the maximum value of 308 (Table 4.3 ).

Although extrinsically the number of geosites is higher in geoarea 1 (geoabundance 1), a larger proportion of the region with a higher rank, intrinsically geoarea 2 indicates a greater abundance (geoabundance 2). Likewise with geodiversity 2 , and therefore, the relevant geological heritage must be considered as more diverse and abundant. Georichness shows the inconsistency between geodiversity and geoabundance areas. 


\section{Additional Criteria to Consider in Determining Geosite (Non Geological Aspects)}

\section{Culture}

As found in the geoarea, the abundant culture of the Dayak ethnic group is scattered, and only a part of it that intersects with a geoarea. As an example, it is the Dayak ethnic group community in the Krayan highlands in the heart of Kalimantan, the Tana Ulen, the Kenyah, the Dayak Basap and the Dayak Lebo ethnic groups in Sangkulirang-Mangkalihat.

In the Iban mountains, the heart of Borneo (HoB), the highlands are the home of the Dayak Lundayeh/Lun Bawang, Sa'ban, Kelabit, and Penan ethnic groups. The site where geosite 1 and 2 are located, Longbawan, is a configuration between special geological features and culture and biodiversity, a blend of natural and artificial landscapes from the agricultural culture of indigenous peoples. Mountain salt production is an important part of the historical and cultural heritage of the people and has become a legend which exists in the Krayan highlands in the HoB (Gani, 2012; Langub, 2012). One of its biodiversity is mentioned in Langub (2012), that Schneeberger (1945) identified specific vegetation that was very similar from the brackish coastal zone as a possible indicator from salt springs and sources. Its traditional cultural construction is not far from Terang Baru village, established on land donated by the local community, organizing a Cultural Field School (CFS), a space for cultural celebrations and to learn traditional music and dance with some antique skills, such as wood carving. Beautiful colored crafts from bamboo and rattan are also produced by local female craftspersons. FORMADAT (Forum of Indigenous Dayak People), is a cross-border customary institution that protects cultural traditions and promotes sustainable development in the Heart of Kalimantan, and increases awareness and understanding of highland communities (WWF Indonesia, 2017).

In the Dayak Kenyah community, the concept of traditional conservation where local wisdom blends with nature is developed, including the possibility that human action can actually preserve and conserve natural resources and help ensure environmental sustainability. Tana Ulen is the name given to forbidden land and is not a special naming for forests in an area. Generally, the expression Tana Ulen refers to stretches of primary forest which are rich in natural resources of high value to local people and serve as a communal reserve forest managed by a local customary institution or the Tana Ulen Management Body (BPTU). Exploitation is usually limited to procuring food for certain events, such as celebrations or rituals of life cycle, because it is bound by special agreements and regulations (Eghenter, 2000). This has become a tradition of the Kenyah people who view nature as a cultural and life heritage. The forbidden land in Malinau approximately covers the Bahau Hulu and Pujungan areas, the central mountain complex of Kalimantan (the Iban Mountains), the oldest rocks in Malinau, Sutura Adio, and Malinau Formation as the ophiolite-melange East zone.

Sangulirang-Mangkalihat is a prehistoric cultural landscape site represented by its karst caves tracks. The Dayak Basap tradition and the Dayak Lebo tradition are mentioned in Sugiyanto (2012) with rock-art culture in East Kalimantan, in their allegations about continuous cultural inheritance and cultural process:

The Dayak Basap ethnic group is scattered in Berau Regency, Sangkulirang district, East Kutai, Segading hamlet in Keraitan Bengalon village, East Kutai, Bajang Tidung hamlet in Sepaso Bengalon village, East Kutai. Some of the Basap people still adhere to nomadic habits, living in rock burrows which are abundant in the karst mountains around their settlements, in Tanjung Mangkaliat, Bukit Hantu (Tendehantu Karst). Likewise with the people of Dayak Lebo who still have kinship with Dayak Basap.

Dayak Lebo has a tradition with the same rock-art cultures. They follows tradition of burial on top or inside a liang (cave) using wooden burial containers called lungun. The life ceremonial tradition which is closely related to the success of the harvest that is unique in its implementation using wood medium which is fully decorated with honeycomb patterns/motifs. The cultural similarity is reflected in the rock-art sites represented by 
honeycomb elements in the rock images and pre-historical lungun sites. Burial sites that have similarities with the Lebo community are Ceruk Lungun in Pengadan village and Liang Lungun in the Marang mountains (Nasruddin 2016). The burial sites for Dayak Lebo are on Mount Badak, Batu Maut, and Mount Ara Raya. A rock-art tradition in the form of a honeycomb motif is Liang Karim. In general, Dayak Lebo is scattered in the Berau and East Kutai districts, especially around the karst areas in Merabu Mapulu, Panaan (Sungai Layan), Tintang (Tukat Canong), and Peronggong, Tabalar, Inaran, Karangan, Baai, Muara Bulan, Bengalon, Tepian Langsat, and Tanjung Mangkalihat. Dayak Basap and Dayak Lebo are closely related in the SangkulirangMangkalihat karst landscape with the exception of the geosites off the coast of Tanjung Mangkalihat.

\section{High Conservation Value Areas}

The focus of the geoarea landscape in this research in Kaltara and Sangkulirang-Mangkalihat is the existence of conservation areas (nature reserve and conservation areas): (i) Kayan Mentarang National Park, (ii) HoB (Heart of Borneo), (iii) Tane Ulen, (iv) Kaltara Karst Area, (v) Nunukan Conservation Area (Sebatik Island), (vi) Sangkulirang Mangkalihat Karst Area, (vii) Berau Regency Conservation Area, namely: (a) Semama Island Wildlife Reserve, Berau Archipelago, and (b) Semama Sangalaki Island Marine Park, Derawan Archipelago, and (ix) other protected areas including protected forest areas and the Sangkulirang-Mangkalihat geological nature preserve area.

The concept of HCV (High Conservation Value) is divided into several HCVs with points and it has been compared with the distribution of intersecting geosites which are considered to have a role by the author, namely 3 out of $6 \mathrm{HCV}$ s determined based on MPH. HCV 1, namely an area that has an important level of biodiversity. HCV 2 is a landscape area that is naturally important for ecological dynamics. HCV 6 is an area that has an important function for the traditional cultural identity of local communities.

\section{Geoconservation}

In Kaltara, 10 major geological interests are identified: geomorphology, hydrology \& hydrogeology, structure, geohistory, sedimentary, mineralogy, igneous rock, geothermal, stratigraphy, and paleontology. In Sangkulirang-Mangkalihat, there are 6 main geological interests: geomorphology, sedimentary, structure, igneous rock, metamorphic rock, and geohistory. Geomorphology is the most common important attraction, accounting for $47 \%$ in Kaltara and $100 \%$ in Sangkulihat.

Geosite typology is considered based on size category. In Kaltara, sites with area typology are the most dominant, then view point typology, and then point. In Sangkulihat, complex typology is the most dominant, then area, and then view point. This classification is used to indicate the most vulnerable geosites (FuertesGutierrez and Fernandez-Martinez, 2010). In this list, the dominant geological heritage sites with a broad typology are both in Kaltara and Sangkulihat, thus the threat of degradation is unlikely. However, if a geological feature has attraction of interest to extractive activities through abundance of elements or rocks, then this large site can become a target for the management of agricultural products including geological resources and forests, so that conservation zoning needs to be protected. Geological features with this typology cover the entire geoarea of the Sangkulihat karst, the Kaltara karst, and the economic potential of other mineral resources.

Regarding the typology of points in Kaltara, the content of scientific and cultural heritage values must be considered. The nine sites comprising $27 \%$ of the typology include heritage sites of salt wells in Krayan and Semolon travertine deposits in Malinau which are of regional heritage value (high). The Krayan salt site is a site of economic value, so that it is full of community activities and Semolon hot springs which is a geotourism icon aking with 7 other sites. 
Sites with special scientific interest feature or within Geological Conservation, they are called Sites of Special Scientific Interest (SSSIs). Reviews on Geological conservation are selected on the basis of scientific values that are superior to educational or historical interests in culture. Selection of the GCR has 3 criteria (Prosser, et al., 2006). The areas suitable for the SSSIs GCR are the geological, scientific and cultural areas of the Sangkulirang-Mangkalihat Karst with global value which have been verified by the Indonesian Geoheritage Commission to UNESCO. Sites with the SSSIs predicated the right to get comprehensive protection against all problems and threats.

The sites with regional interest in geology and geomorphology features, or RIGS (Regionally Important Geological and Geomorphological Sites), has the site's value for educational purposes and interests in the continuous learning process. Sites with the title RIGS spread across Kaltara include: the Longbawan mountains, the Longbawan salt wells, the Semolon hot springs, the Sembakung meander river system and oxbow lake, the Rian volcano, the Tarakan delta, the Bulungan karst, the Kayan River fluvial lowlands, and the ancient Nunukan volcano. RIGS according to English Nature may not have protection of law, but there are many local planning authorities at the suggestion of stakeholder groups. It is in contrast to the case with geological conservation in Indonesia which emphasizes more on features rather than groups of scientific interest predicate. Therefore, geological conservation is regulated by law and its appropriate derivatives.

\section{Geosite assessment complies with legal protection and legal awareness}

Only 30.7\% in Kaltara and 95.5\% in Sangkulirang-Mangkalihat of the inventoried geosite are in areas with conservation/legal protection. These protected areas include the Heart of Borneo, National Parks, Geological Nature Preserves, Wildlife Areas, Nature Conservation Areas, Nature Tourism Parks, and other Protected Forest Areas (Table 4.4). Even so, conservation protection is attached to legal provisions but it still overlaps with production forest areas (limited to permanent) and mining areas (based on forest zoning map, 2016).

Some of the geosites outside the conservation areas are in geotourism areas, development areas, and between areas full of construction. According to Moura et al (2017), the relationship between conservation and legal protection frameworks and vulnerability is a major indication where geosites need urgent protection. In this case, the geosite point typology that is in the construction area and without legal protection is the most vulnerable.

\section{Sites with intrinsic value/scientific interest features}

Three inside zoning for conservation areas in Eastern Part of Kalimantan are formulated, namely:

Figure 4. Geoconservation zoning map of the geological landscape of the Eastern Part of Kalimantan

Zone 1, the highest geoheritage value, covers all the limestone and karsts of Sangkulirang-Mangkalihat, has the SSSIs predicate, and has a prominent or high global heritage value or ranking. This geosite contains very important scientific and aesthetic features, such as karst landscapes, caves, prehistoric sites, triangular facet landscapes, ophiolites, coastal features, atoll islands, and exquisite sceneries. Formations of limestone, endokarsts, exokarsts or karst landscapes, and perikarst above them which are the source of life for important species, become the source of upstream for various river water flows in East Kalimantan, and therefore this area is very sensitive to any forms of disturbance at the slightest.

Zone 2, medium geoheritage value, covers all major regional heritage sites which are prominent or high with the title of RIGs, and is spread over Kaltara covering the Krayan highlands representing the landscape of the raised Miri zone and subsurface anhydrite deposits. Nunukan Island regarding fossils of ancient volcanoes, Malinau as an opening trace of magmatism in the Cenozoic in Kaltara, and Bulungan with its limestone formations are included in this zone. 
Zone 3, low geoheritage value, is a collection of sites with important local heritage values and good geotourism or geological outcrops to study for field-class activities (fieldtrip).

\section{Conclusion}

An assessment of the geological heritage sites in the Eastern Part of Kalimantan allows us in making some general conclusions, namely:

1. The identification of the diversity of geological heritage reveals that the geological features in the Eastern Part of Kalimantan are very diverse and contain high scientific, aesthetic, cultural, and biodiversity values. Geoarea 1 consists of 53 homogeneous geosites or 26 heterogeneous geosites, the actual geodiversity value is 0.114 with a geological abundance of 0.17 (geoabundance), with a complexity percentage of $100 \%$. Geoarea 2 has 178 homogeneous geosites or 22 heterogeneous geosites. There are 8 geological hotspots consisting of 13 geosites and 14 types of geosites. The actual value of geodiversity is 3.272 with a geological abundance of 20.2 (geoabundance), and a complexity of $100 \%$.

2. Great natural and anthropic threats. In Kaltara, sites with typology areas are the most dominant, then view point typology, and then point. Ten (10) geological sites of special interest are identified: geomorphology, hydrology \& hydrogeology, structure, geohistory, sedimentary, mineralogy, igneous rock, geothermal, stratigraphy, and paleontology. In Sangkulihat, complex typology is the most dominant, then area, and then view point. Six (6) main geological sites are identified: geomorphology, sedimentary, structure, igneous rock, metamorphic rock, geohistory. Geomorphology is the most common important attraction, accounting for $47 \%$ in Kaltara and $100 \%$ in Sangkulihat. As much as $30.7 \%$ in Kaltara and $95.5 \%$ in SangkulirangMangkalihat of the inventoried geosites are under the conservation/legal protection.

3. Sites with SSSIs and RIGS values can be applied to the Indonesian landscape and can adapted to the Indonesian legal protection for better geoconservation protection.

\section{Acknowledgement}

The author would like to thank Prof Hendarmawan, Dr. Vijaya Isnania Wardhani and Prof Mega Fatimah Rosana, for her guidance, all authors in these references for all data and information that can be accessed and used.

\section{References}

Andriany, S.S. 2015. Memuliakan Bumi dan Mensejahterakan Masyarakat Melalui Program Geopark (Studi Kasus Ciletuh). Karya Tulis Ilmiah. Sumedang: Universitas Padjadjaran.

Águeda Villar, J.A., et al. 2009. Spanish Geological Frameworks and Geosites: An approach to Spanish geological heritage of international relevance. Madrid. Instituto Geológico y Minero de España. Publications of The Geological Survey of Spain (IGME).

Baillie, P et al. 2004. Deformation of cenozoic basins of Borneo and West Sulawesi. Indonesian Petroleum Association, Proceedings, Deepwater and Frontier Exploration In Asia \& Australasia Symposium.

Bemmelen, R.W.V. 1949. The Geology of Indonesia Vol. IA General Geology of Indonesia and Adjacent Archipelagoes. Government Printing Office, The Hague.

Brocx, M., Semeniuk, V. 2007. Geodiversity and geoconservation - history, definition, scope, and scale. Australia : Journal of The Royal Society of Western Australia.

Delegasi Republik Indonesia untuk UNESCO. 2015. Sangkulirang-Mangkalihat Karst: Prehistoric rock art area. [Online]. Available at http://whc.unesco.org/en/tentativelists/6009/ (diakses 6 April 2018).

Eghenter, Cristina. 2000. What is Tana Ulen Good for? considerations on indigenous forest management, conservation, and research in the interior of Indonesian Borneo. Human Ecology: An Interdisciplinary Journal, vol 28 (3): 331-357.

Fernández-Martínez, E and Fuertes-Gutiérrez. 2010. Geosites inventory in the Leon province (Northwestern Spain): A tool to introduce geoheritage into regional environmental management. Spain : Springer-Verlag 2010; Geoheritage 2010. 
Gani, Nicholas. 2012. Salt production in Long Midang, Krayan. East Kalimantan. Borneo Research Bulletin, vol 43: 216224.

Hjort, J., Gray, M. 2015. Why geodiversity matters in valuing nature's stage: why geodiversity matters. Society for Conservation Biology: Conservation Biology,Volume 00, No. 0, 1-10.

Kementerian Lingkungan Hidup dan Kehutanan. 2005. Derawan Islands. [Online]. Available at http://whc.unesco.org/en/tentativelists/2007/ (diakses 6 April 2018).

Langub, J. 2012. Krayan Highland salt in Central Borneo: its uses and significance. Borneo Research Bulletin, vol 43: 186204.

Moura, P., et al. 2017. Conservation of geosites as a tool to protect geoheritage: the inventory of Ceara Central Domain, Borborema Province - NE/ Brazil. Brazil : Annals of the Brazilian Academy of Sciences.

Moss, S., Wilson, M. 1998. Biogeographic implication of the Tertiary paleogeographic evolution of Sulawesi and Borneo. Biogeography and Geological Evolution of SE Asia, pp. 133-163. Backhuys Publishers, Leiden, The Netherlands.

Neches, I. 2016. Geodiversity beyond material evidence: a Geosite Type based interpretation of geological heritage. Proceedings of the Geologists' Association 127 (2016) 78-89.

Prosser, C., et al. 2006. Geological Conservation: a guide to good practice. England. English Nature.

Ramadan, P. R. 2018. Identifikasi dan Konservasi Warisan Bumi Bersifat Natural (Geologi) di Kalimantan Bagian Timur Berdasarkan Analisis Geodiversitas (aspiring Geopark). Universitas Padjadjaran, tidak dipublikasikan.

Ruban, Dimitry A. 2010. Quantification of geodiversity and its loss. Proceedings of the Geologists' Association 121 (2010) 326-333.

Sallam, Emad S., et al. 2018. Geological heritage diversity in the Faiyum Oasis (Egypt): A comprehensive assessment. Journal of African Earth Sciences 140 (2018) 212-224

Sugiyanto, Bambang. 2012. Tradisi Dayak Lebo dan budaya rock-art di Kalimantan Timur. Naditira Widya, vol 6 (1): 16-26, Balai Arkeologi Banjarmasin.

Soeria-Atmaja, R., Noeradi, D., Priadi, B. 1999. Cenozoic magmatism in Kalimantan and its related geodynamic evolution. Journal of Asian Earth Sciences 17; Elsevier Science Ltd.

The United Nations Educational, Scientific and Cultural Organization (UNESCO). 2014. Guidelines and criteria for national geoparks seeking UNESCO's assistance to join the Global Geoparks Network (GGN). Paris : UNESCO. [Online].

William A. P. WIMBLEDON. 1999. GEOSITES - an International Union of Geological Sciences initiative to conserve our geological heritage. Polish Geological Institute Special Papers, 2 : 5-8.

Wilson, Moyra E.J., et al. 1998. Cenozoic carbonates in Borneo: case studies from Northeast Kalimantan. Journal of Asian Earth Science, Elsevier Science Ltd.

Wilson, Moyra E.J. and Evans, Martin J. 2002. Sedimentology and diagenesis of Tertiary carbonateson the Mangkalihat Peninsula, Borneo: implications for subsurface reservoir quality. Marine and Petroleum Geology 19 (2002) 873-900, Elsevier Science Ltd.

World Wide Fund For Nature Indonesia. 2015. Mountain salt from the Krayan Highlands in the Hearth of Borneo. [Online]. Available at www.wwf.panda.org/?240371/Mountain-Salt $\quad$ (diakses $26 \quad$ Maret 2018) 


\section{Appendices}

Appendix 1. Simplified Geological Map of Kalimantan (Left)(Moss and Wilson, 1998), (Right)(Wilson et al., 1999), shows outcrops and some sub-outcrops of Cenozoic Carbonate and modern carbonate deposition systems

Appendix 2. Geosite inventory of geoarea 1 in the pie chart (left: geosite typology data; Right: geosite data per geosite type)

Appendix 3. Geosite inventory of geoarea 2 in the pie chart (Left: geosite typology data; Right: geosite data per geosite type)

Appendix 4. Table of geosites protected according to the designation of conservation areas

\begin{tabular}{|l|l|l|}
\hline Legal Basis & Geosite & Conservation Area \\
\hline $\begin{array}{l}\text { Declaration on the Hearth of Borneo Initiative } \\
\text { Three Countries, One Conservation Vision, 2007 }\end{array}$ & $\begin{array}{l}\text { Krayan Salt Well (anhydrite deposit) } \\
\text { Tectonic-structure of the Krayan highlands } \\
\text { Martin Bila Waterfall } \\
\text { Part of Bulungan karst } \\
\text { Balatikon Village River, Sebuku }\end{array}$ & $\begin{array}{l}\text { Heart of Kalimantan (Heart of } \\
\text { Borneo) }\end{array}$ \\
\hline Minister of Forestry Decree No. 631/Kpts-II/1996 & Kayan Mentarang National Park & Sebatik Island Protected Forest \\
\hline Minister of Forestry Decree No. 631/Kpts-II/1999 & Batulamampu Beach & \\
\hline
\end{tabular}


Mohamad Sapari Dwi Hadian et al. / Identification and conservation of geoheritage (geology) based on geodiversity analysis

\begin{tabular}{|c|c|c|}
\hline $\begin{array}{l}\text { Decree of the Regent of Nununkan No. } 43 \text { and } 44 \\
2007\end{array}$ & & \\
\hline Minister of Forestry Decree No 295/Kpts-II/1996 & Nunukan Island Ancient Volcano & Nunukan Island Protected Forest \\
\hline $\begin{array}{l}\text { East Kalimantan Governor Regulation No. } 67 \text { of } \\
2012\end{array}$ & $\begin{array}{l}\text { Karsts of Biatan Ulu, Inaran, Semurut, Gua Mulut Besar, Merabu, Bayan-Kongbeng, Marang, } \\
\text { Baai, Pengadan, Briun, Biatantengah, Sekerat-Sepatan, Madadem Mountain, Sepinang, Biduk- } \\
\text { Biduk, Tanjung Mangkalihat Ophiolite, Mangkalihat-Tindihantu-Kaniungan, Mount Beriun }\end{array}$ & $\begin{array}{l}\text { Sangkulirang-Mangkalihat } \\
\text { Geological Nature Reserve Area }\end{array}$ \\
\hline $\begin{array}{l}\text { Minister of Marine Affairs and Fisheries No. } \\
\text { 87/Kepmen-KP/2016 }\end{array}$ & $\begin{array}{l}\text { Maratua Island } \\
\text { Kakaban Island }\end{array}$ & Berau Regency Conservation Area \\
\hline $\begin{array}{l}\text { Minister of Agriculture Decree No. } \\
604 / \mathrm{Kpts} / \mathrm{Um} / 8 / 1982\end{array}$ & Karang Muaras & $\begin{array}{l}\text { Semama Island Wildlife Reserve } \\
\text { Area }\end{array}$ \\
\hline $\begin{array}{l}\text { Minister of Agriculture Decree No. } \\
\text { 604/Kpts/Um/8/1982 }\end{array}$ & & $\begin{array}{l}\text { Semama Sangalaki Island Marine } \\
\text { Park }\end{array}$ \\
\hline
\end{tabular}


Appendix 5. Geodiversity quantitative assessment, a brief overview showing the number of geosites, geosites types, geosites per geosite type, geological hotspot/geodiversity LOCI in North Kalimantan

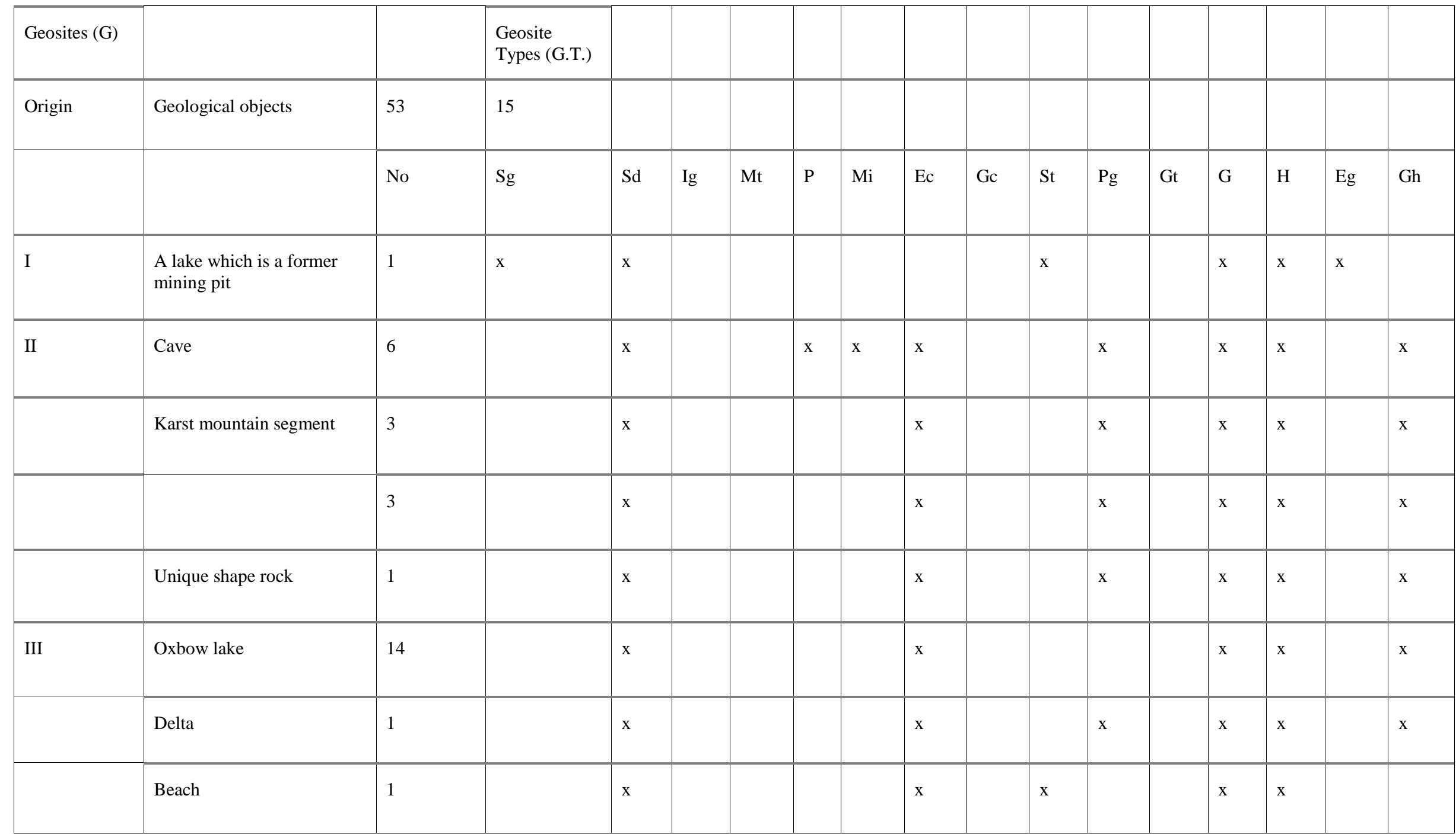


Mohamad Sapari Dwi Hadian et al. / Identification and conservation of geoheritage (geology) based on geodiversity analysis

\begin{tabular}{|c|c|c|c|c|c|c|c|c|c|c|c|c|c|c|c|c|}
\hline IV & Waterfall & 1 & $\mathrm{x}$ & $\mathrm{x}$ & & & $\mathrm{x}$ & & & & $\mathrm{x}$ & & & $\mathrm{x}$ & $\mathrm{x}$ & \\
\hline & & 1 & $\mathrm{x}$ & $\mathrm{x}$ & & & & & & & $\mathrm{x}$ & & & $\mathrm{x}$ & $\mathrm{x}$ & \\
\hline & & 1 & & $\mathrm{x}$ & & & & & & & $\mathrm{x}$ & & & $\mathrm{x}$ & $\mathrm{x}$ & \\
\hline & Inland river & 1 & & $\mathrm{x}$ & & & & & $\mathrm{x}$ & & $\mathrm{x}$ & & & $\mathrm{x}$ & $\mathrm{x}$ & \\
\hline \multirow[t]{3}{*}{ V } & Hot springs & 2 & & $\mathrm{x}$ & & & & $\mathrm{x}$ & $\mathrm{x}$ & $\mathrm{x}$ & $\mathrm{x}$ & & $X$ & & $\mathrm{x}$ & \\
\hline & & 1 & $\mathrm{x}$ & $\mathrm{x}$ & & & & $\mathrm{x}$ & $\mathrm{x}$ & $\mathrm{x}$ & $\mathrm{x}$ & & $\mathrm{X}$ & & $\mathrm{x}$ & \\
\hline & & 1 & & $\mathrm{x}$ & $\mathrm{x}$ & & & $\mathrm{x}$ & $\mathrm{x}$ & $\mathrm{x}$ & $\mathrm{x}$ & & $\mathrm{X}$ & & $\mathrm{x}$ & \\
\hline \multirow[t]{2}{*}{ VII } & Structural hill & 1 & & $\mathrm{x}$ & & & & & & & $\mathrm{x}$ & $\mathrm{x}$ & & $\mathrm{x}$ & & $\mathrm{x}$ \\
\hline & Structural valley & 1 & & $\mathrm{x}$ & & & & & $\mathrm{x}$ & & $\mathrm{x}$ & $\mathrm{x}$ & & $\mathrm{x}$ & & $\mathrm{x}$ \\
\hline VIII & Alluvial lowlands & 1 & & & & & & & $\mathrm{x}$ & & & $\mathrm{x}$ & & $\mathrm{x}$ & $\mathrm{x}$ & $\mathrm{x}$ \\
\hline \multirow[t]{2}{*}{ IX } & $\begin{array}{l}\text { Mambunut ancient volcano } \\
\text { (hogback basalt andesite } \\
\text { lava) }\end{array}$ & 1 & & & $\mathrm{x}$ & & & & $\mathrm{x}$ & & $\mathrm{x}$ & $\mathrm{x}$ & & $\mathrm{x}$ & & $\mathrm{x}$ \\
\hline & $\begin{array}{l}\text { Upstream Sei Apok ancient } \\
\text { volcano }\end{array}$ & 1 & & $\mathrm{x}$ & $\mathrm{x}$ & $\mathrm{x}$ & & $\mathrm{x}$ & $\mathrm{x}$ & & & $\mathrm{x}$ & & $\mathrm{x}$ & & $\mathrm{x}$ \\
\hline
\end{tabular}


Proceeding of the $5^{\text {th }}$ International Conference of Geological Engineering Faculty, Vol. 1, Issue 2, 2020, pp. 08-35

\begin{tabular}{|c|c|c|c|c|c|c|c|c|c|c|c|c|c|c|c|c|c|}
\hline & $\begin{array}{l}\text { Tanjungbatu ancient } \\
\text { volcano }\end{array}$ & 2 & & $\mathrm{x}$ & $\mathrm{x}$ & & & & & & $\mathrm{x}$ & $\mathrm{x}$ & & $\mathrm{x}$ & & & $\mathrm{x}$ \\
\hline & Tanjungbatu basalt lava & 1 & & & $\mathrm{x}$ & & & & & & $\mathrm{x}$ & $\mathrm{x}$ & & $\mathrm{x}$ & & & $\mathrm{x}$ \\
\hline & Panamas ancient volcano & 1 & & & $\mathrm{x}$ & & & & & & & $\mathrm{x}$ & & $\mathrm{x}$ & & & $\mathrm{x}$ \\
\hline & $\begin{array}{l}\text { Gunungapi purba } \\
\text { Kampungbaru }\end{array}$ & 1 & & $\mathrm{x}$ & $\mathrm{x}$ & & & & $\mathrm{x}$ & & & $\mathrm{x}$ & & $\mathrm{x}$ & & & $\mathrm{x}$ \\
\hline & Rian volcano (Sumbat lava) & 1 & & & $\mathrm{x}$ & & & & & $\mathrm{x}$ & $\mathrm{x}$ & $\mathrm{x}$ & & $\mathrm{x}$ & & & $\mathrm{x}$ \\
\hline & Waterfall & 1 & & & $\mathrm{x}$ & & & & & & $\mathrm{x}$ & $\mathrm{x}$ & & $\mathrm{x}$ & $\mathrm{x}$ & & $\mathrm{x}$ \\
\hline $\mathrm{X}$ & Salt dome & 1 & & $\mathrm{x}$ & & & & $\mathrm{x}$ & $\mathrm{x}$ & $\mathrm{x}$ & $\mathrm{x}$ & $\mathrm{x}$ & & & $\mathrm{x}$ & & $\mathrm{x}$ \\
\hline & Rock outcrop & 1 & $\mathrm{x}$ & $\mathrm{x}$ & & & & & & & $\mathrm{x}$ & $\mathrm{x}$ & & & & & $\mathrm{x}$ \\
\hline & & 1 & & $\mathrm{x}$ & & & $\mathrm{x}$ & & & & & $\mathrm{x}$ & & $\mathrm{x}$ & $\mathrm{x}$ & & $\mathrm{x}$ \\
\hline LOCI & 0 & G/G.T. & $\mathrm{Sg}$ & $\mathrm{Sd}$ & Ig & Mt & $\mathrm{P}$ & $\mathrm{Mi}$ & $\mathrm{Ec}$ & $\mathrm{Gc}$ & St & $\mathrm{Pg}$ & $\mathrm{Gt}$ & G & $\mathrm{H}$ & $\mathrm{Eg}$ & Gh \\
\hline & & & 5 & 47 & 10 & 1 & 8 & 12 & 40 & 6 & 20 & 29 & 4 & 47 & 42 & 1 & 43 \\
\hline
\end{tabular}


Appendix 6. Geodiversity quantitative assessment, a brief overview showing the number of geosites, geosite types, geosites per geosite type, geological hotspot/geodiversity LOCI in East Kalimantan

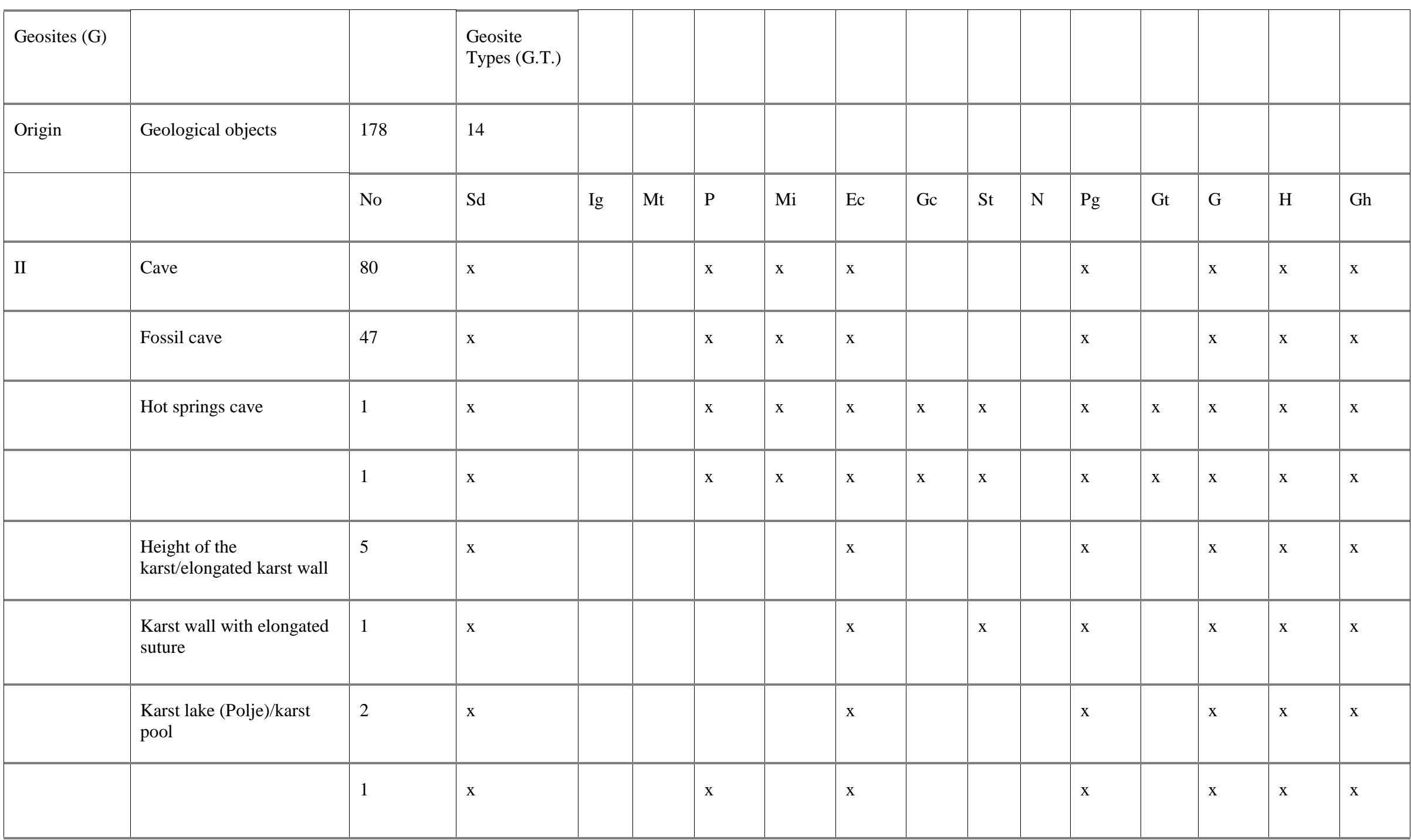


Proceeding of the $5^{\text {th }}$ International Conference of Geological Engineering Faculty, Vol. 1, Issue 2, 2020, pp. 08-35

\begin{tabular}{|c|c|c|c|c|c|c|c|c|c|c|c|c|c|}
\hline & & 1 & $\mathrm{x}$ & $\mathrm{x}$ & & & & & $\mathrm{x}$ & & $\mathrm{x}$ & $\mathrm{x}$ & $\mathrm{x}$ \\
\hline & $\begin{array}{l}\text { Underwater spring karst } \\
\text { pool }\end{array}$ & 1 & $\mathrm{x}$ & $\mathrm{x}$ & & & & & $\mathrm{x}$ & & $\mathrm{x}$ & $\mathrm{x}$ & $\mathrm{x}$ \\
\hline & Rimstone pool & 1 & $\mathrm{x}$ & $\mathrm{x}$ & $\mathrm{x}$ & & & & $\mathrm{x}$ & & $\mathrm{x}$ & $\mathrm{x}$ & $\mathrm{x}$ \\
\hline & $\begin{array}{l}\text { Tower karst } \\
\text { group/segment }\end{array}$ & 1 & $\mathrm{x}$ & & & $\mathrm{x}$ & & & $\mathrm{x}$ & & $\mathrm{x}$ & $\mathrm{x}$ & $\mathrm{x}$ \\
\hline & $\begin{array}{l}\text { Cockpit karst } \\
\text { group/segment }\end{array}$ & 9 & $\mathrm{x}$ & & & $\mathrm{x}$ & & & $\mathrm{x}$ & & $\mathrm{x}$ & $\mathrm{x}$ & $\mathrm{x}$ \\
\hline & & 2 & $\mathrm{x}$ & & & $\mathrm{x}$ & & $\mathrm{x}$ & $\mathrm{x}$ & & $\mathrm{x}$ & $\mathrm{x}$ & $\mathrm{x}$ \\
\hline & $\begin{array}{l}\text { Wavy topography karst } \\
\text { group/segment }\end{array}$ & 7 & $\mathrm{x}$ & & & $\mathrm{x}$ & & & $\mathrm{x}$ & & $\mathrm{x}$ & $\mathrm{x}$ & $\mathrm{x}$ \\
\hline & Karst river/stream section & 1 & $\mathrm{x}$ & & & $\mathrm{x}$ & & & $\mathrm{x}$ & & $\mathrm{x}$ & $\mathrm{x}$ & $\mathrm{x}$ \\
\hline III & Waterfall & 1 & $\mathrm{x}$ & & & & & & $\mathrm{x}$ & & $\mathrm{x}$ & $\mathrm{x}$ & $\mathrm{x}$ \\
\hline & & 1 & $\mathrm{x}$ & $\mathrm{x}$ & & $\mathrm{x}$ & & & $\mathrm{x}$ & & $\mathrm{x}$ & $\mathrm{x}$ & $\mathrm{x}$ \\
\hline & Fresh and sald water lakes & 1 & $\mathrm{x}$ & & & $\mathrm{x}$ & & & $\mathrm{x}$ & & $\mathrm{x}$ & $\mathrm{x}$ & $\mathrm{x}$ \\
\hline V & Hot springs & 2 & $\mathrm{x}$ & & & & $\mathrm{x}$ & & & $\mathrm{x}$ & & $\mathrm{x}$ & $\mathrm{x}$ \\
\hline & & 1 & $\mathrm{x}$ & & & & $x$ & & & $\mathrm{x}$ & & $\mathrm{x}$ & $\mathrm{x}$ \\
\hline
\end{tabular}




\begin{tabular}{|c|c|c|c|c|c|c|c|c|c|c|c|c|c|c|c|c|}
\hline VI & Bay & 2 & $\mathrm{x}$ & & & & & $\mathrm{x}$ & & & & & & $\mathrm{x}$ & & \\
\hline & Ophiolite & 1 & $\mathrm{x}$ & $\mathrm{x}$ & $\mathrm{x}$ & & $\mathrm{x}$ & & & & & $\mathrm{x}$ & & $\mathrm{x}$ & & $\mathrm{x}$ \\
\hline & Brackish lake & 1 & $\mathrm{x}$ & & & $\mathrm{x}$ & & $\mathrm{x}$ & & & & $\mathrm{x}$ & & $\mathrm{x}$ & $\mathrm{x}$ & $\mathrm{x}$ \\
\hline & Atoll & 3 & $\mathrm{x}$ & & & $\mathrm{x}$ & & $\mathrm{x}$ & & & & $\mathrm{x}$ & & $\mathrm{x}$ & $\mathrm{x}$ & $\mathrm{x}$ \\
\hline & Coral island & 1 & $\mathrm{x}$ & & & $\mathrm{x}$ & & $\mathrm{x}$ & & & & $\mathrm{x}$ & & $\mathrm{x}$ & $\mathrm{x}$ & $\mathrm{x}$ \\
\hline VII & Triangular facet & 3 & $\mathrm{x}$ & & & & & & & $\mathrm{x}$ & $\mathrm{x}$ & & & $\mathrm{x}$ & & $\mathrm{x}$ \\
\hline LOCI & 8 & G/G.T. & $\mathrm{Sd}$ & $\mathrm{Ig}$ & Mt & $\mathrm{P}$ & $\mathrm{Mi}$ & Ec & $\mathrm{Gc}$ & St & $\mathrm{N}$ & $\mathrm{Pg}$ & Gt & G & $\mathrm{H}$ & Gh \\
\hline & & & 178 & 1 & 1 & 139 & 131 & 167 & 5 & 8 & 3 & 170 & 5 & 175 & 172 & 176 \\
\hline
\end{tabular}

Origin: II, karst; III, hydrogeomorphology; V, hydrothermal; VI, tectonics; VII, tektonics-strukture; Geosite types: Sd, sediment \& sedimentary rock; Ig, igneous petrology; Mt, metamorphic rock petrology; P, paleontology; Mi, mineralogy; Ec, economy; Gc, geochemistry; St, structure; N, neotectonics; Pg, paleogeography; Gt, geothermal; G, geomorphology; H, hydrology \& hydrogeology; Gh, geohistory. 
APPENDIX 7. The value of Kaltara geological heritage sites.

\begin{tabular}{|c|c|c|c|c|c|c|c|c|c|c|c|c|}
\hline Geosite & Station & Size & Representation & Uniqueness & Scarcity & Economy & $\begin{array}{l}\text { Significance } \\
\text { (Semeniuk, } \\
\text { 1968; 1987; } \\
\text { 2007) }\end{array}$ & $\begin{array}{l}\text { Value } \\
\text { (Ibrahim } \\
\text { Komoo } \\
\text { and UU } \\
\text { No. } \\
\text { 26/2007) }\end{array}$ & $\begin{array}{l}\text { mGT } \\
\text { (main } \\
\text { interest } \\
\text { of } \\
\text { geosite } \\
\text { types) }\end{array}$ & $\begin{array}{l}\mathrm{C} \text { (additional } \\
\text { criteria } \\
\text { considered) }\end{array}$ & $\begin{array}{l}\text { HV } \\
\text { (heritage } \\
\text { logarithmic } \\
\text { value) }\end{array}$ & Intrinsics \\
\hline $\begin{array}{l}\text { Krayan } \\
\text { highland } \\
\text { Tectonics- } \\
\text { Structure }\end{array}$ & gs1 & $50 \mathrm{~km} 2$ & Structure & $\begin{array}{l}\text { Village in } \\
\text { highlands, } \\
\text { folded } \\
\text { mountains }\end{array}$ & Landscape & $\begin{array}{l}\text { Valley that } \\
\text { become } \\
\text { field, } \\
\text { geotourism }\end{array}$ & Regional & Medium & $\begin{array}{l}\mathrm{G}+\mathrm{St} \\
+\mathrm{Gh}\end{array}$ & $\begin{array}{l}\text { Special } \\
\text { ecological } \\
\text { function }\end{array}$ & 0.01 & \\
\hline $\begin{array}{l}\text { Anhydrite } \\
\text { deposit }\end{array}$ & gs2 & Point & $\begin{array}{l}\text { Sedimentary, } \\
\text { mineralogy }\end{array}$ & $\begin{array}{l}\text { Salt dome, } \\
\text { anhydrite } \\
\text { mineral }\end{array}$ & $\begin{array}{l}\text { Salt water } \\
\text { manifestation } \\
\text { in mountains, } \\
\text { salt dome }\end{array}$ & $\begin{array}{l}\text { Mountain } \\
\text { salt, } \\
\text { geotourism }\end{array}$ & Regional & High & $\mathrm{Sd}+\mathrm{Mi}$ & $\begin{array}{l}\text { Degree of } \\
\text { conservation, } \\
\text { related to the } \\
\text { folklore of the } \\
\text { Dayak } \\
\text { Lundayeh } \\
\text { ethnic group }\end{array}$ & 0.01 & \\
\hline $\begin{array}{l}\text { Jelai } \\
\text { Tertiary } \\
\text { Magmatic } \\
\text { Arc }\end{array}$ & gs9 & $33 \mathrm{~km} 2$ & $\begin{array}{l}\text { Tertiary } \\
\text { volcano }\end{array}$ & $\begin{array}{l}\text { Volcanic plug, } \\
\text { igneous rock }\end{array}$ & Lava plug & $\begin{array}{l}\text { Andesite } \\
\text { lava, } \\
\text { geotourism }\end{array}$ & Regional & High & $\mathrm{Ig}+\mathrm{Gh}$ & $\begin{array}{l}\text { Degree of } \\
\text { conservation, } \\
\text { tropical forest } \\
\text { and special } \\
\text { ecological } \\
\text { function }\end{array}$ & 0.01 & \\
\hline
\end{tabular}




\begin{tabular}{|c|c|c|c|c|c|c|c|c|c|c|c|}
\hline $\begin{array}{l}\text { Nunukan } \\
\text { ancient } \\
\text { volcano }\end{array}$ & gs 26 & $\begin{array}{l}81,65 \\
\mathrm{~km} 2\end{array}$ & $\begin{array}{l}\text { Tertiary ancient } \\
\text { volcano of } \\
\text { swamp } \\
\text { environment }\end{array}$ & $\begin{array}{l}\text { Basalt lava } \\
\text { with the shape } \\
\text { of hogback } \\
\text { hills, pillow } \\
\text { lava, stocky } \\
\text { column }\end{array}$ & $\begin{array}{l}\text { Basalt lava } \\
\text { with the shape } \\
\text { of hogback } \\
\text { hills, pillow } \\
\text { lava, stocky } \\
\text { column }\end{array}$ & $\begin{array}{l}\text { Andesite } \\
\text { lava, } \\
\text { geotourism }\end{array}$ & Regional & Prominent & $\begin{array}{l}\mathrm{Ig}+\mathrm{St} \\
+\mathrm{Gh}\end{array}$ & - & 0.01 \\
\hline $\begin{array}{l}\text { Tertiary } \\
\text { Karst Hills }\end{array}$ & $\begin{array}{l}\text { gs12, } \\
\text { gs } 14, \\
\text { gs16, } \\
\text { gs17, } \\
\text { gs18, } \\
\text { gs19, } \\
\text { gs20 }\end{array}$ & $\begin{array}{l}312851 \\
\text { ha }\end{array}$ & $\begin{array}{l}\text { Sembakung } \\
\text { limestone and } \\
\text { karst formation }\end{array}$ & $\begin{array}{l}\text { Seemingly } \\
\text { piled up rocks } \\
\text { from erosion } \\
\text { and } \\
\text { karstification, } \\
\text { karst towers, } \\
\text { karst cones, } \\
\text { caves, } \\
\text { speleotems: } \\
\text { stalagmites \& } \\
\text { stalagtites, in } \\
\text { the forms of } \\
\text { poles, temple, } \\
\text { stairs, curtain- } \\
\text { like patterns, } \\
\text { travertine, } \\
\text { view point of } \\
\text { the Kayan } \\
\text { river alluvial- } \\
\text { fluvial plain }\end{array}$ & $\begin{array}{l}\text { Landscape, } \\
\text { travertine }\end{array}$ & geotourism & Regional & High & $\begin{array}{l}\mathrm{G}+\mathrm{Sd} \\
+\mathrm{Sp}+ \\
\mathrm{Gh}\end{array}$ & $\begin{array}{l}\text { Degree of } \\
\text { conservation, } \\
\text { special } \\
\text { ecological } \\
\text { function, } \\
\text { archaeological } \\
\text { remains }\end{array}$ & 0.01 \\
\hline \multirow[t]{2}{*}{$\begin{array}{l}\text { Non- } \\
\text { volcanic } \\
\text { geothermal }\end{array}$} & $\begin{array}{l}\text { gs } 11 \\
\text { gs } 23\end{array}$ & Point & $\begin{array}{l}\text { Non-volcanic } \\
\text { geothermal }\end{array}$ & $\begin{array}{l}\text { Not associated } \\
\text { with } \\
\text { volcanoes, } \\
\text { travertine } \\
\text { deposits that } \\
\text { form pools }\end{array}$ & $\begin{array}{l}\text { Travertine, } \\
\text { clay minerals } \\
\text { and sulfur } \\
\text { deposits }\end{array}$ & geotourism & Regional & High & $\mathrm{Gt}+\mathrm{Mi}$ & Fault zone & 0.01 \\
\hline & $\begin{array}{l}\text { gs4, } \\
\text { gs10 }\end{array}$ & Point & $\begin{array}{l}\text { Non-volcanic } \\
\text { geothermal }\end{array}$ & $\begin{array}{l}\text { Not associated } \\
\text { with } \\
\text { volcanoes }\end{array}$ & - & geotourism & Local & Medium & Gt & Fault zone & 0.001 \\
\hline
\end{tabular}


Proceeding of the $5^{\text {th }}$ International Conference of Geological Engineering Faculty, Vol. 1, Issue 2, 2020, pp. 08-35

\begin{tabular}{|c|c|c|c|c|c|c|c|c|c|c|c|}
\hline $\begin{array}{l}\text { Tarakan } \\
\text { Delta }\end{array}$ & gs 13 & $\begin{array}{l}1342 \\
\mathrm{~km} 2\end{array}$ & Delta system & $\begin{array}{l}\text { Arcuate delta, } \\
\text { Scorched } \\
\text { islands }\end{array}$ & - & $\begin{array}{l}\text { Fish ponds } \\
\text { and } \\
\text { agriculture }\end{array}$ & Regional & High & $\begin{array}{l}\mathrm{G}, \mathrm{H}, \\
\mathrm{Sd}\end{array}$ & $\begin{array}{l}\text { Degree of } \\
\text { conservation, } \\
\text { geological } \\
\text { process }\end{array}$ & 0.01 \\
\hline $\begin{array}{l}\text { Alluvial- } \\
\text { Fluvial } \\
\text { Plain }\end{array}$ & gs 15 & - & $\begin{array}{l}\text { Alluvial-fluvial } \\
\text { lowlands }\end{array}$ & $\begin{array}{l}\text { Landscape } \\
\text { view point }\end{array}$ & $\begin{array}{l}\text { Landscape } \\
\text { view point }\end{array}$ & Geotourism & Regional & High & G & $\begin{array}{l}\text { Degree of } \\
\text { conservation, } \\
\text { geological and } \\
\text { anthropic } \\
\text { landscapes }\end{array}$ & 0.01 \\
\hline Oxbow lake & gs5 & $\begin{array}{l}166 \mathrm{~km} \\
\text { length } \\
\text { and area } \\
\text { of } 212 \\
\mathrm{~km} 2\end{array}$ & $\begin{array}{l}\text { Meandering } \\
\text { river and } \\
\text { oxbow lake }\end{array}$ & Landscape & Landscape & $\begin{array}{l}\text { Geotourism, } \\
\text { fish ponds }\end{array}$ & Regional & High & $\mathrm{G}, \mathrm{H}$ & $\begin{array}{l}\text { Degree of } \\
\text { conservation, } \\
\text { special } \\
\text { ecological } \\
\text { function }\end{array}$ & 0.01 \\
\hline $\begin{array}{l}\text { Siltstone } \\
\text { outcrops } \\
\text { and } \\
\text { Limestone } \\
\text { and } \\
\text { Sandstone } \\
\text { inserts }\end{array}$ & gs22 & $\begin{array}{l}50 \mathrm{~m} \\
\text { outcrop } \\
\text { length }\end{array}$ & Rock outcrop & - & - & - & Local & Low & $\begin{array}{l}\mathrm{Sd}+\mathrm{Sg} \\
+\mathrm{St}\end{array}$ & - & 0.001 \\
\hline $\begin{array}{l}\text { Limestone } \\
\text { outcrops }\end{array}$ & gs24 & $\begin{array}{l}30 \mathrm{~m} \\
\text { outcrop } \\
\text { length }\end{array}$ & $\begin{array}{l}\text { Sajau } \\
\text { formation } \\
\text { limestone }\end{array}$ & - & - & - & Local & Low & $\mathrm{Sd}+\mathrm{P}$ & - & 0.001 \\
\hline $\begin{array}{l}\text { Sianak } \\
\text { waterfall }\end{array}$ & gs6 & - & - & - & - & Geotourism & Local & Low & $\mathrm{Sd}+\mathrm{Sg}$ & - & 0.001 \\
\hline $\begin{array}{l}\text { Martin Bila } \\
\text { waterfall }\end{array}$ & gs25 & - & - & - & - & Geotourism & Local & Medium & G & $\begin{array}{l}\text { Special } \\
\text { ecological } \\
\text { function }\end{array}$ & 0.001 \\
\hline
\end{tabular}


Mohamad Sapari Dwi Hadian et al. / Identification and conservation of geoheritage (geology) based on geodiversity analysis

\begin{tabular}{|c|c|c|c|c|c|c|c|c|c|c|c|}
\hline $\begin{array}{l}\text { Idaman } \\
\text { waterfall }\end{array}$ & gs 21 & - & - & $\begin{array}{l}\text { 3-level } \\
\text { waterfall } \\
\text { (fault } \\
\text { structure) }\end{array}$ & $\begin{array}{l}\text { Wood fossil } \\
\text { fragments }\end{array}$ & Geotourism & Local & Medium & $\begin{array}{l}\mathrm{Sd}+\mathrm{Sg} \\
+\mathrm{St}+\mathrm{P}\end{array}$ & $\begin{array}{l}\text { Special } \\
\text { ecological } \\
\text { function }\end{array}$ & 0.001 \\
\hline Beach & gs7 & - & - & - & - & Geotourism & Local & Low & G & - & 0.001 \\
\hline $\begin{array}{l}\text { Stream } \\
\text { section }\end{array}$ & gs3 & - & - & - & - & Geotourism & Local & Low & G & $\begin{array}{l}\text { Special } \\
\text { ecological } \\
\text { function }\end{array}$ & 0.001 \\
\hline Green lake & gs8 & - & $\begin{array}{l}\text { Anthropogenic } \\
\text { land form }\end{array}$ & $\begin{array}{l}\text { Green-colored } \\
\text { lake }\end{array}$ & - & Geotourism & Local & Low & $\mathrm{Eg}$ & $\begin{array}{l}\text { Anthropic } \\
\text { landscape }\end{array}$ & 0.001 \\
\hline
\end{tabular}


APPENDIX 8. The value of Sangkulirang-Mangkalihat geological heritage sites.

\begin{tabular}{|c|c|c|c|c|c|c|c|c|c|c|c|c|}
\hline Geosite & Station & Size & $\begin{array}{l}\text { Representatio } \\
\mathrm{n}\end{array}$ & Uniqueness & Scarcity & Economy & $\begin{array}{l}\text { Significanc } \\
\text { e } \\
\text { (Semeniuk, } \\
\text { 1968; 1987; } \\
\text { 2007) }\end{array}$ & $\begin{array}{l}\text { Value } \\
\text { (Ibrahim } \\
\text { Komoo } \\
\text { and UU } \\
\text { No. } \\
\text { 26/2007) }\end{array}$ & $\begin{array}{l}\text { mGT } \\
\text { (main } \\
\text { interest } \\
\text { of } \\
\text { geosite } \\
\text { types) }\end{array}$ & $\begin{array}{l}\mathrm{C} \\
\text { (additional } \\
\text { criteria } \\
\text { considered) }\end{array}$ & $\begin{array}{l}\text { HV } \\
\text { (heritage } \\
\text { logarithmi } \\
\text { c value) }\end{array}$ & $\begin{array}{l}\text { Intrinsic } \\
\mathrm{s}\end{array}$ \\
\hline $\begin{array}{l}\text { Cenozoic } \\
\text { Carbonate }\end{array}$ & $\begin{array}{l}\text { gs1, } \\
\text { gs2, gs3, } \\
\text { gs4, } \\
\text { gs5, gs6, } \\
\text { gs7, } \\
\text { gs8, gs9, } \\
\text { gs10, } \\
\text { gs11, } \\
\text { gs12, } \\
\text { gs13, } \\
\text { gs14, } \\
\text { gs15, } \\
\text { gs16, } \\
\text { gs17, } \\
\text { gs18, } \\
\text { gs19, gs21 }\end{array}$ & $\begin{array}{l}26 \\
\mathrm{~km} 2, \\
11,71 \\
\mathrm{~km} 2, \\
90,37 \\
\mathrm{~km} 2, \\
55,21 \\
\mathrm{~km} 2, \\
221,4 \\
\mathrm{~km} 2, \\
29,31 \\
\mathrm{~km} 2, \\
31,53 \\
\mathrm{~km} 2, \\
302,1 \\
\mathrm{~km} 2, \\
100 \\
\mathrm{~m} 2, \\
63,3 \\
\mathrm{~km} 2, \\
43,53 \\
\mathrm{~km} 2, \\
142,8 \\
\mathrm{~km} 2,\end{array}$ & $\begin{array}{l}\text { Limestones of } \\
\text { Kedango, } \\
\text { Seilor } \\
\text { formation, } \\
\text { Tabalar } \\
\text { formation, } \\
\text { Domaring } \\
\text { formation, } \\
\text { and } \\
\text { Tendehantu } \\
\text { formation }\end{array}$ & $\begin{array}{l}\text { largest karst } \\
\text { landscapes, } \\
\text { modern karst } \\
\text { formations, } \\
\text { cockpits, towers, } \\
\text { karst cones, } \\
\text { dolina, uvala, } \\
\text { polje, rimstone } \\
\text { pools, karst } \\
\text { waterfalls, } \\
\text { stream section, } \\
\text { karst cliffs, giant } \\
\text { karst walls }\end{array}$ & $\begin{array}{l}\text { modern karst } \\
\text { formations, } \\
\text { cockpits, towers, } \\
\text { karst cones, } \\
\text { dolina, uvala, } \\
\text { polje, rimstone } \\
\text { pools, karst } \\
\text { waterfalls, } \\
\text { stream section }\end{array}$ & $\begin{array}{l}\text { Geotouris } \\
\mathrm{m}\end{array}$ & Global & Prominent & $\mathrm{G}, \mathrm{Sd}$ & $\begin{array}{l}\text { Degree of } \\
\text { conservation } \\
\text {, special } \\
\text { ecological } \\
\text { function, } \\
\text { pre-historic } \\
\text { site of the } \\
\text { world, } \\
\text { tentative list } \\
\text { of UNESCO } \\
\text { geoheritage } \\
\text { sites }\end{array}$ & 1 & \\
\hline
\end{tabular}


Mohamad Sapari Dwi Hadian et al. / Identification and conservation of geoheritage (geology) based on geodiversity analysis

\begin{tabular}{|c|c|c|c|c|c|c|c|c|c|c|}
\hline & & $\begin{array}{l}6,9 \\
\mathrm{~km} 2, \\
166,5 \\
\mathrm{~km} 2, \\
636,8 \\
\mathrm{~km} 2, \\
110,6 \\
\mathrm{~km} 2, \\
302,4 \\
\mathrm{~km} 2, \\
249,8 \\
\mathrm{~km} 2, \\
252,5 \\
\mathrm{~km} 2, \\
482,4 \\
\mathrm{~km} 2,\end{array}$ & & & & & & & & \\
\hline $\begin{array}{l}\text { Cenozoic } \\
\text { Carbonate }\end{array}$ & $\begin{array}{l}\text { gs } 4, \text { gs } 13, \\
\text { gs14, gs15 }\end{array}$ & $\begin{array}{l}55,21 \\
\mathrm{~km} 2, \\
6,9 \\
\mathrm{~km} 2, \\
166,5 \\
\mathrm{~km} 2, \\
636,8 \\
\mathrm{~km} 2\end{array}$ & $\begin{array}{l}\text { Limestones of } \\
\text { Kedango, } \\
\text { Seilor } \\
\text { formation, } \\
\text { Tabalar } \\
\text { formation, } \\
\text { Domaring } \\
\text { formation, } \\
\text { Tendehantu } \\
\text { formation }\end{array}$ & $\begin{array}{l}\text { largest karst } \\
\text { landscapes, } \\
\text { modern karst } \\
\text { formations, } \\
\text { cockpits, towers, } \\
\text { karst cones, } \\
\text { dolina, uvala, } \\
\text { polje, rimstone } \\
\text { pools, karst } \\
\text { waterfalls, } \\
\text { stream section, } \\
\text { karst cliffs, giant } \\
\text { karst walls }\end{array}$ & $\begin{array}{l}\text { Geotouris } \\
\mathrm{m}\end{array}$ & Global & Prominent & $\mathrm{G}, \mathrm{Sd}$ & $\begin{array}{l}\text { Degree of } \\
\text { conservation } \\
\text {, special } \\
\text { ecological } \\
\text { function, } \\
\text { pre-historic } \\
\text { site of the } \\
\text { world, } \\
\text { tentative list } \\
\text { of UNESCO } \\
\text { geoheritage } \\
\text { sites }\end{array}$ & 1 \\
\hline
\end{tabular}


Proceeding of the $5^{\text {th }}$ International Conference of Geological Engineering Faculty, Vol. 1, Issue 2, 2020, pp. 08-35

\begin{tabular}{|c|c|c|c|c|c|c|c|c|c|c|c|}
\hline $\begin{array}{l}\text { Atoll } \\
\text { Coral }\end{array}$ & $\mathrm{gs} 1, \mathrm{gs} 2$ & $\begin{array}{l}26 \\
\mathrm{~km} 2 \\
11,71 \\
\mathrm{~km} 2\end{array}$ & $\begin{array}{l}\text { Sediments of } \\
\text { Seilor } \\
\text { formation, } \\
\text { implications } \\
\text { of Maratua } \\
\text { fault zone }\end{array}$ & $\begin{array}{l}\text { Atoll coral } \\
\text { island, jellyfish } \\
\text { lake }\end{array}$ & $\begin{array}{l}\text { Atoll, jellyfish } \\
\text { lake }\end{array}$ & $\begin{array}{l}\text { Geotouris } \\
\mathrm{m}\end{array}$ & Global & Prominent & $\mathrm{G}, \mathrm{Sd}$ & $\begin{array}{l}\text { Degree of } \\
\text { conservation } \\
\text {, special } \\
\text { ecological } \\
\text { function, } \\
\text { pre-historic } \\
\text { site of the } \\
\text { world, } \\
\text { tentative list } \\
\text { of UNESCO } \\
\text { geoheritage } \\
\text { sites }\end{array}$ & 1 \\
\hline $\begin{array}{l}\text { Atoll } \\
\text { Coral }\end{array}$ & gs3 & $\begin{array}{l}90,37 \\
\mathrm{~km} 2\end{array}$ & $\begin{array}{l}\text { Sediments of } \\
\text { Seilor } \\
\text { formation, } \\
\text { implications } \\
\text { of Maratua } \\
\text { fault zone }\end{array}$ & Atoll Coral & Atoll & $\begin{array}{l}\text { Geotouris } \\
\mathrm{m}\end{array}$ & Global & Prominent & $\mathrm{G}, \mathrm{Sd}$ & $\begin{array}{l}\text { Degree of } \\
\text { conservation } \\
\text {, special } \\
\text { ecological } \\
\text { function, } \\
\text { pre-historic } \\
\text { site of the } \\
\text { world, } \\
\text { tentative list } \\
\text { of UNESCO } \\
\text { geoheritage } \\
\text { sites }\end{array}$ & 1 \\
\hline $\begin{array}{l}\text { Mount } \\
\text { Beriun } \\
\text { fault zone }\end{array}$ & gs22 & $\begin{array}{l}179,5 \\
\mathrm{~km} 2\end{array}$ & Structure & $\begin{array}{l}\text { Triangular facet } \\
\text { ravines/mountain } \\
\mathrm{s}\end{array}$ & $\begin{array}{l}\text { Triangular facet } \\
\text { ravines/mountain } \\
\mathrm{s}\end{array}$ & - & Regional & Prominent & $\mathrm{G}, \mathrm{St}$ & $\begin{array}{l}\text { Degree of } \\
\text { conservation } \\
\text {, special } \\
\text { ecological } \\
\text { function }\end{array}$ & 0.01 \\
\hline $\begin{array}{l}\text { Ophiolite } \\
\text { complex }\end{array}$ & gs20 & $\begin{array}{l}16,55 \\
\mathrm{~km} 2\end{array}$ & $\begin{array}{l}\text { Pre-Tertiary } \\
\text { sedimentary } \\
\text { rocks and } \\
\text { ophiolites }\end{array}$ & $\begin{array}{l}\text { Oldest rocks and } \\
\text { bancuh rocks }\end{array}$ & $\begin{array}{l}\text { Oldest rocks and } \\
\text { bancuh rocks }\end{array}$ & - & Regional & Prominent & $\begin{array}{l}\text { Sd, Ig, } \\
\text { Mt, St, } \\
\text { Gh }\end{array}$ & $\begin{array}{l}\text { Degree of } \\
\text { conservation }\end{array}$ & 0.01 \\
\hline
\end{tabular}

